\title{
Estradiol-Mediated Spine Changes in the Dorsal Hippocampus and Medial Prefrontal Cortex of Ovariectomized Female Mice Depend on ERK and mTOR Activation in the Dorsal Hippocampus
}

\author{
Jennifer J. Tuscher, ${ }^{1}$ Victoria Luine, ${ }^{2}$ Maya Frankfurt, ${ }^{3 *}$ and Karyn M. Frick ${ }^{1 *}$ \\ ${ }^{1}$ Department of Psychology, University of Wisconsin-Milwaukee, Milwaukee, Wisconsin 53211, 2Department of Psychology, Hunter College of the City \\ University of New York, New York, New York 10065, and ${ }^{3}$ Department of Science Education, Hofstra North Shore-LIJ School of Medicine, Hempstead, New \\ York 11549
}

Dendritic spine plasticity underlies the formation and maintenance of memories. Both natural fluctuations and systemic administration of $17 \beta$-estradiol $\left(\mathrm{E}_{2}\right)$ alter spine density in the dorsal hippocampus $(\mathrm{DH})$ of rodents. $\mathrm{DH} \mathrm{E}_{2}$ infusion enhances hippocampal-dependent memory by rapidly activating extracellular signal-regulated kinase (ERK)-dependent signaling of mammalian target of rapamycin (mTOR), a key protein synthesis pathway involved in spine remodeling. Here, we investigated whether infusion of $\mathrm{E}_{2}$ directly into the $\mathrm{DH}$ drives spine changes in the $\mathrm{DH}$ and other brain regions, and identified cell-signaling pathways that mediate these effects. $\mathrm{E}_{2}$ significantly increased basal and apical spine density on CA1 pyramidal neurons $30 \mathrm{~min}$ and $2 \mathrm{~h}$ after infusion. $\mathrm{DH} \mathrm{E}_{2}$ infusion also significantly increased basal spine density on pyramidal neurons in the medial prefrontal cortex $(\mathrm{mPFC}) 2 \mathrm{~h}$ later, suggesting that $\mathrm{E}_{2}$-mediated activity in the $\mathrm{DH}$ drives mPFC spinogenesis. The increase in $\mathrm{CA} 1$ and $\mathrm{mPFC}$ spine density observed $2 \mathrm{~h}$ after intracerebroventricular infusion of $\mathrm{E}_{2}$ was blocked by DH infusion of an ERK or mTOR inhibitor. DH $\mathrm{E}_{2}$ infusion did not affect spine density in the dentate gyrus or ventromedial hypothalamus, suggesting specific effects of $\mathrm{E}_{2}$ on the $\mathrm{DH}$ and $\mathrm{mPFC}$. Collectively, these data demonstrate that $\mathrm{DH} \mathrm{E}_{2}$ treatment elicits ERK- and mTOR-dependent spinogenesis on CA1 and mPFC pyramidal neurons, effects that may support the memory-enhancing effects of $\mathrm{E}_{2}$.

Key words: CA1; dendritic spine density; estrogen; mPFC; pyramidal neuron; spinogenesis

\section{Significance Statement}

Although systemically injected $17 \beta$-estradiol $\left(\mathrm{E}_{2}\right)$ increases CA1 dendritic spine density, the molecular mechanisms regulating $\mathrm{E}_{2}$-induced spinogenesis in vivo are largely unknown. We found that $\mathrm{E}_{2}$ infused directly into the dorsal hippocampus (DH) increased CA 1 spine density $30 \mathrm{~min}$ and $2 \mathrm{~h}$ later. Surprisingly, $\mathrm{DH} \mathrm{E}_{2}$ infusion also increased spine density in the medial prefrontal cortex (mPFC), suggesting that estrogenic regulation of the DH influences mPFC spinogenesis. Moreover, inhibition of ERK and mTOR activation in the DH prevented $\mathrm{E}_{2}$ from increasing DH and $\mathrm{mPFC}$ spines, demonstrating that DH ERK and $\mathrm{mTOR}$ activation is necessary for $\mathrm{E}_{2}$-induced spinogenesis in the $\mathrm{DH}$ and $\mathrm{mPFC}$. These findings provide novel insights into the molecular mechanisms through which $\mathrm{E}_{2}$ mediates dendritic spine density in CA1 and mPFC.

\section{Introduction}

The ability of $17 \beta$-estradiol $\left(\mathrm{E}_{2}\right)$ to increase dendritic spine density on CA1 pyramidal neurons in ovariectomized female rats is one of the most seminal and replicated findings in behavioral neuroendocrinology (Gould et al., 1990; Woolley et al., 1990; Woolley and McEwen, 1993; MacLusky et al., 2005; Phan et al.,

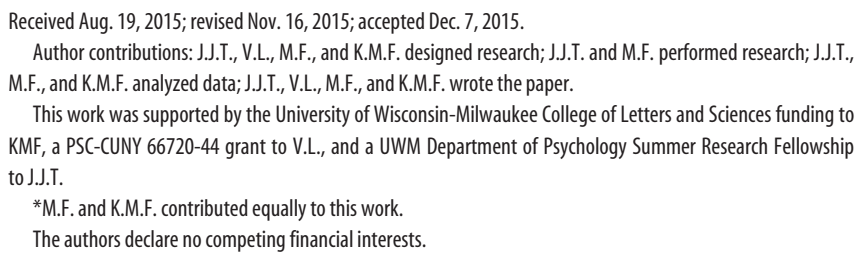

The authors declare no competing financial interests.

This article is freely available online through the J Neurosci Author Open Choice option.

Correspondence should be addressed to Dr. Karyn M. Frick, Department of Psychology, University of WisconsinMilwaukee, 2441 East Hartford Avenue, Milwaukee, WI 53211. E-mail: frickk@uwm.edu.

DOI:10.1523/JNEUROSCI.3135-15.2016

Copyright ( 2016 Tuscher et al.

This is an Open Access article distributed under the terms of the Creative Commons Attribution License Creative Commons Attribution 4.0 International, which permits unrestricted use, distribution and reproduction in any medium provided that the original work is properly attributed. 
2012), yet the molecular mechanisms regulating $\mathrm{E}_{2}$-induced spinogenesis in the hippocampus and elsewhere in the brain remain largely unclear. In the dorsal hippocampus $(\mathrm{DH}), \mathrm{E}_{2}$ significantly increases CA1 dendritic spine density within $30 \mathrm{~min}$ of systemic injection (MacLusky et al., 2005; Inagaki et al., 2012). The $\mathrm{E}_{2}$-induced facilitation of spinogenesis peaks 2-3 d after systemic injection (Woolley and McEwen, 1993) and is associated with enhanced hippocampal synaptic plasticity (Woolley et al., 1997; Foy et al., 1999; Mukai et al., 2007) and memory formation (Inagaki et al., 2012; Phan et al., 2012). $\mathrm{E}_{2}$ also affects spinogenesis in other brain regions that mediate learning and memory, such as the medial prefrontal cortex (mPFC; Kesner et al., 1996; Inagaki et al., 2012; Yang et al., 2014), where $\mathrm{E}_{2}$ increases pyramidal spine density from $30 \mathrm{~min}$ to $24 \mathrm{~h}$ after systemic injection (Inagaki et al., 2012; Phan et al., 2012). Given the putative role of spinogenesis in synaptic plasticity, estrogenic regulation of spines in regions, such as the $\mathrm{DH}$ and $\mathrm{mPFC}$, is likely instrumental for $\mathrm{E}_{2}$ to regulate memory formation (Luine and Frankfurt, 2013).

However, the molecular mechanisms through which $\mathrm{E}_{2}$ regulates in vivo spine density are unclear. Spinogenesis requires protein synthesis, which could occur via nuclear transcriptional or by local protein synthesis within dendrites. The rapidity with which $\mathrm{E}_{2}$ mediates spinogenesis suggests the involvement of local protein synthesis mechanisms such as mammalian target of rapamycin (mTOR) signaling (Hoeffer and Klann, 2010). mTOR is activated by multiple kinases, including extracellular signalregulated kinase (ERK; Ma et al., 2007; Winter et al., 2011). Within the $\mathrm{DH}$, activation of ERK and mTOR is necessary for $\mathrm{E}_{2}$ to enhance object recognition and spatial memory consolidation in ovariectomized female mice (Fortress et al., 2013). Specifically, DH infusion of the ERK inhibitor U0126 or mTOR inhibitor rapamycin prevents $\mathrm{E}_{2}$ from enhancing memory and increasing p42 ERK phosphorylation (Fernandez et al., 2008; Fortress et al., 2013). Given the importance of DH ERK and mTOR activation for $\mathrm{E}_{2}$-induced memory enhancement, we hypothesized that these signaling pathways would also be involved in $\mathrm{E}_{2}$-induced spinogenesis. Although ERK activation is necessary for $E_{2}$ to increase dendritic spines in cultured cortical and hippocampal neurons and slices (Mukai et al., 2007; Srivastava et al., 2008; Hasegawa et al., 2015; Murakami et al., 2015), the involvement of ERK and mTOR activation in $\mathrm{E}_{2}$-mediated spinogenesis in vivo is unknown.

We tested whether $\mathrm{DH}$ infusion of $\mathrm{E}_{2}$ regulates dendritic spine density in the $\mathrm{DH}$ and other brain regions, and examined the contribution of DH ERK and mTOR activation to $\mathrm{E}_{2}$-induced spinogenesis. $\mathrm{DH}$-infused $\mathrm{E}_{2}$ increased dendritic spine density within $30 \mathrm{~min}$ in the $\mathrm{DH}$ and within $2 \mathrm{~h}$ in the $\mathrm{mPFC}$, suggesting that $\mathrm{E}_{2}$-induced $\mathrm{DH}$ spinogenesis may drive $\mathrm{MPFC}$ spinogenesis. Moreover, $\mathrm{E}_{2}$-induced spine changes in both brain regions required ERK and mTOR activation in the $\mathrm{DH}$, providing the first evidence that specific cell-signaling pathways regulate $E_{2}$ induced spinogenesis in vivo.

\section{Materials and Methods}

Subjects. Experiments used 8- to 12-week-old female C57BL/6 mice (Taconic Biosciences) as subjects ( $n=5-7 /$ group). Mice were group-housed until surgery, after which they were singly housed. Mice were maintained on a $12 \mathrm{~h}$ light/dark cycle with ad libitum access to food and water. All procedures were approved by the University of Wisconsin-Milwaukee Institutional Animal Care and Use Committee in accordance with the National Institutes of Health Guide for the Care and Use of Laboratory Animals.

Surgery. Immediately before surgery, mice received $5 \mathrm{mg} / \mathrm{kg}$ of Rimadyl subcutaneously for pain management. They were anesthetized with isoflurane in $100 \%$ oxygen and placed in a stereotaxic apparatus for ovariectomy and cannula implantation (Boulware et al., 2013; Fortress et al., 2013). Mice were implanted with stainless steel bilateral guide cannulae (Plastics One) aimed at the DH only [C232GC, 22 gauge; $-1.7 \mathrm{~mm}$ $\mathrm{AP}, \pm 1.5 \mathrm{~mm} \mathrm{ML}$, and $-2.3 \mathrm{~mm} \mathrm{DV}$ (injection site)] or at the $\mathrm{DH}$ and dorsal third ventricle [intracerebroventricular (ICV); C232GC, 22 gauge; $-0.9 \mathrm{~mm} \mathrm{AP}, \pm 0.0 \mathrm{~mm} \mathrm{ML}$, and $-2.8 \mathrm{~mm} \mathrm{DV}$ (injection site)]. Cannulae were fixed to the skull with dental cement (Darby Dental) that also closed the wound. Dummy cannulae (C232DC; Plastics One) were used to prevent clogging. Postsurgical analgesia was provided by MediGel CPF $\left(\mathrm{ClearH}_{2} \mathrm{O}\right)$. Mice recovered 1 week before infusion.

Drugs and Infusions. In Experiment 1, mice received bilateral DH infusions of vehicle or $\mathrm{E}_{2}$ and were killed 30 min or $2 \mathrm{~h}$ later. Hydroxypropyl- $\beta$ cyclodextrin (HBC)-encapsulated $\mathrm{E}_{2}$ (Sigma-Aldrich) was dissolved in $0.9 \%$ sterile saline to $10 \mu \mathrm{g} / \mu \mathrm{l}$ and infused at $0.5 \mu \mathrm{l} / \mathrm{min}$ for $1 \mathrm{~min} / \mathrm{hemisphere}$ (Fernandez et al., 2008; Fortress et al., 2013). The vehicle was HBC (SigmaAldrich) dissolved in saline to the same concentration of cyclodextrin present in the $\mathrm{E}_{2}$ solution. In Experiment 2, mice received DH infusion of DMSO vehicle or a cell-signaling inhibitor, followed immediately by ICV infusion of $\mathrm{HBC}$ vehicle or $\mathrm{E}_{2}$ (Fortress et al., 2013). The MEK inhibitor 1,4-diamino2,3-dicyano-1,4-bis(o-aminophenyl-mercapto)butadiene (U0126; Promega) was dissolved in 50\% DMSO to $1.0 \mu \mathrm{g} / \mu \mathrm{l}$, and the mTOR inhibitor rapamycin was dissolved in 50\% DMSO to $0.025 \mathrm{ng} / \mu \mathrm{l}$. Bilateral DH infusions of $0.5 \mu \mathrm{l}$ DMSO vehicle, U0126, or rapamycin were immediately followed by ICV infusion $(0.5 \mu \mathrm{l} / \mathrm{min}$ for $2 \mathrm{~min})$ of $10 \mu \mathrm{g} / \mu \mathrm{lE} \mathrm{E}_{2}$ or HBC vehicle. Bilateral DH infusion of $5 \mu \mathrm{gE}_{2}$ or ICV infusion of $10 \mu \mathrm{g} \mathrm{E}_{2}$ enhances object recognition and object placement memory in ovariectomized mice (Boulware et al., 2013; Fortress et al., 2013).

Golgi impregnation and spine counting. Mice were cervically dislocated and decapitated $30 \mathrm{~min}$ or $2 \mathrm{~h}$ after infusion. Golgi impregnation was performed as described previously (Frankfurt et al., 2011) using the Rapid GolgiStain Kit (FD NeuroTechnologies). Secondary basal dendrites and tertiary apical dendrites were counted blindly from pyramidal neurons in dorsal hippocampal CA1 and layer II/III of the prelimbic $\mathrm{mPFC}$. Spines were also counted on granule cells and neurons from the ventromedial hypothalamic nucleus (VMN). Dendrites from six cells/ region/brain were included in the analysis, and five to seven brains were quantified/group. Neurons were chosen for analyses as described previously (Luine et al., 2006). Spines were counted on a Nikon Eclipse E400 microscope under oil $(100 \times)$ using a hand counter, and dendritic length was measured using Spot Advanced v5.0 Windows (Diagnostic Instruments). Spine density was calculated by dividing spine number by dendrite length. Data were expressed as number of spines $/ 10 \mu \mathrm{m}$ dendrite.

Data Analysis. For Experiment 1 ( $\mathrm{E}_{2}$ only), two-way ANOVAs (treatment $X$ time) were conducted separately for apical and basal spine density in each brain region. For Experiment 2 ( $E_{2}$ plus inhibitors), one-way ANOVAs were conducted to measure treatment effects on spines $2 \mathrm{~h}$ postinfusion. Post hoc tests (Tukey, Fisher's least significance difference) assessed between-group differences.

\section{Results}

\section{$\mathrm{DH} \mathrm{E}_{2}$ infusion increased CA1 spine density $30 \mathrm{~min}$ and}

\section{$2 \mathrm{~h}$ later}

Main effects of treatment and time were significant for basal (Fig. $1 A ; F_{(1,22)}=63.37, p<0.0001$ and $F_{(1,22)}=8.93, p=0.007$, respectively) and apical (Fig. $1 B ; F_{(1,22)}=46.46, p<0.0001$ and $F_{(1,22)}=7.25, p=0.013$, respectively) CA1 dendrites. Relative to vehicle, $\mathrm{E}_{2}$ increased CA1 basal $(p<0.0001)$ and apical $(p<$ $0.01)$ spine density within $30 \mathrm{~min}$. This effect remained significant for both basal and apical dendrites $2 \mathrm{~h}$ after infusion $(p$ values $<0.0001)$. These data demonstrate that $\mathrm{DH} \mathrm{E}_{2}$ infusion induces a rapid increase in apical and basal CA1 spine density that lasts at least $2 \mathrm{~h}$.

\section{DH $E_{2}$ infusion did not affect spine density in the dentate gyrus}

To demonstrate specificity of $\mathrm{E}_{2}$ effects within the $\mathrm{DH}$, we examined dendritic spine density in the dentate gyrus, which exhibits 

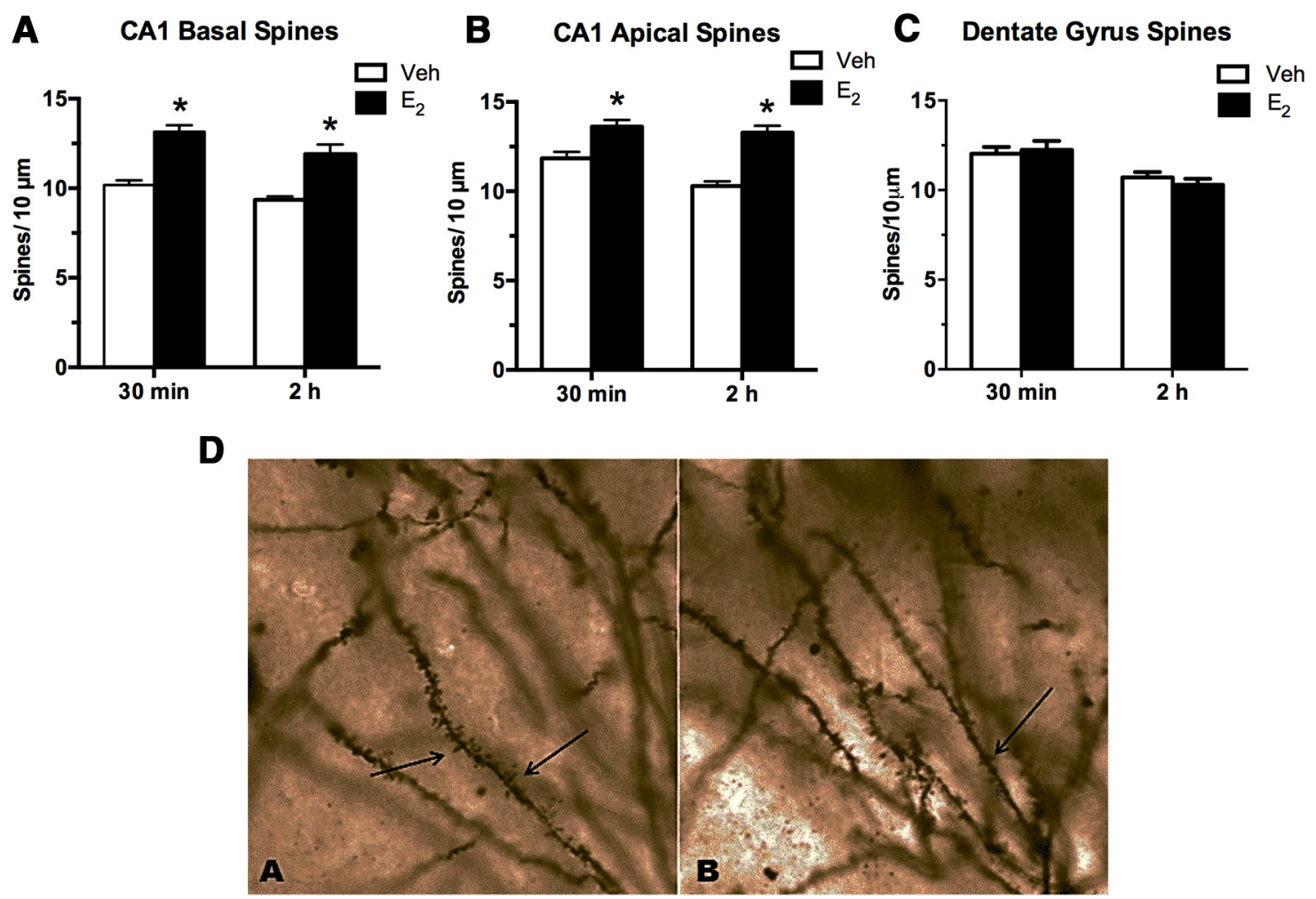

Figure 1. $E_{2}$ increased CA1 spine density $30 \mathrm{~min}$ and $2 \mathrm{~h}$ after DH infusion. Relative to vehicle, basal $(\boldsymbol{A})$ and apical $(\boldsymbol{B}) \mathrm{CA} 1 \mathrm{spine}$ density were increased $30 \mathrm{~min}$ and $2 \mathrm{~h}$ after $\mathrm{DH}$ infusion of 5 $\mu \mathrm{g} /$ hemisphere $\mathrm{E}_{2} \cdot \mathrm{C}_{1} \mathrm{E}_{2}$ did not significantly alter dentate gyrus spine density at either time point. Bars represent the mean $\pm \mathrm{SEM} .{ }^{*} p<0.05$. D, Photomicrograph of Golgi-impregnated secondary basal dendrites of $C A 1$ pyramidal cells $\left(A, E_{2} ; B\right.$, vehicle). Arrows denote spines. Under oil $100 \times$.

increased neurogenesis in response to $\mathrm{E}_{2}$ (Tanapat et al., 2005; Galea et al., 2006; Barha et al., 2009). The main effect of time was significant $\left(F_{(1,20)}=18.13, p=0.0004\right)$, such that fewer spines were observed $2 \mathrm{~h}$ after infusion than $30 \mathrm{~min}$ after infusion (Fig. $1 C)$. However, $\mathrm{E}_{2}$ had no effect on spines at either time point $(p>$ $0.05)$.

DH infusion of $E_{2}$ increased basal spine density in mPFC $2 \mathrm{~h}$ after infusion

Main effects of treatment $\left(F_{(1,20)}=18.47, p=0.0004\right)$ and time $\left(F_{(1,20)}=17.3, p=0.0005\right)$ were significant for basal mPFC dendrites (Fig. $2 A)$, as was the main effect of treatment $\left(F_{(1,20)}=5.0\right.$, $p=0.037$ ) for apical mPFC dendrites (Fig. 2B). $\mathrm{DH} \mathrm{E}_{2}$ infusion did not significantly alter apical or basal spine density in the $\mathrm{mPFC} 30 \mathrm{~min}$ later, although a trend for an increase was evident for both types of spines. Indeed, $\mathrm{E}_{2}$ significantly increased basal $(p<0.01$ ), but not apical, spine density $2 \mathrm{~h}$ later (Fig. $2 A, B$ ). Thus, $\mathrm{DH} \mathrm{E}_{2}$ infusion increased basal spine density in the mPFC within $2 \mathrm{~h}$, suggesting that estrogenic regulation of $\mathrm{DH}$ spinogenesis may alter mPFC spine morphology.

\section{$\mathrm{E}_{2}$ did not influence spine density in the VMN}

The effects of $\mathrm{DH} \mathrm{E}_{2}$ infusion on $\mathrm{mPFC}$ spines might result from exogenous $E_{2}$ diffusing outside of the $\mathrm{DH}$. Because systemic $\mathrm{E}_{2}$ treatment increases spinogenesis in the VMN, we examined spine density in this region (Frankfurt et al., 1990). The main effect of time was significant $\left(F_{(1,22)}=24.1, p<0.0001\right)$, such that fewer spines were observed $2 \mathrm{~h}$ after infusion than $30 \mathrm{~min}$ after infusion (Fig. 2C). However, no effect of $\mathrm{E}_{2}$ was observed at either time point ( $p$ values $>0.05$ ). These data support a more specific effect of $\mathrm{DH} \mathrm{E}_{2}$ infusion on mPFC spine density.
$\mathrm{E}_{2}$-induced spine changes in the $\mathrm{DH}$ and $\mathrm{mPFC}$ depend on DH ERK and mTOR signaling

To determine whether $\mathrm{E}_{2}$-induced spine changes in CA1 and mPFC depend upon rapid activation of ERK and mTOR signaling, mice received bilateral DH infusions of DMSO vehicle, the ERK inhibitor U0126, or the mTOR inhibitor rapamycin, followed immediately by ICV infusion of $\mathrm{HBC}$ vehicle or $\mathrm{E}_{2}$. Brains were collected $2 \mathrm{~h}$ later. Importantly, the inhibitor doses used do not impair object recognition memory or p42-ERK phosphorylation on their own, yet block the memory-enhancing effects of $\mathrm{E}_{2}$ (Fortress et al., 2013). In CA1, the main effect of group was significant for basal $\left(F_{(3,22)}=10.59, p=0.0002\right.$; Fig. $\left.3 A\right)$ and apical $\left(F_{(3,22)}=6.11, p=0.004\right.$; Fig. $\left.3 B\right)$ spines. Mice receiving $\mathrm{E}_{2}+$ vehicle exhibited a significant increase in basal $(p<0.01)$ and apical $(p<0.05)$ CA1 spine density $2 \mathrm{~h}$ after infusion relative to vehicle controls. This increase was blocked for basal and apical spines (Fig. $3 A, B)$ in mice receiving DH infusions of $\mathrm{U} 0126(p<$ 0.001 relative to $\mathrm{E}_{2}+$ vehicle) or rapamycin $(p<0.01$ relative to $\mathrm{E}_{2}+$ vehicle), suggesting that ERK and mTOR activation are necessary for $\mathrm{E}_{2}$ to increase CA1 spine density.

Interestingly, DH ERK and mTOR activation also regulated mPFC spine formation. mPFC spine density was significantly altered $2 \mathrm{~h}$ after infusion for basal $\left(F_{(3,19)}=11.49, p=0.0002\right)$ and apical $\left(F_{(3,19)}=7.04, p=0.002\right)$ spines. As in CA1, mice infused with $\mathrm{E}_{2}+$ vehicle exhibited significantly greater basal $(p<0.01)$ and apical $(p<0.01)$ spine density than vehicle controls. Again, these increases were blocked by U0126 $(p<0.01$ relative to $\mathrm{E}_{2}+$ vehicle $)$ or rapamycin $(p<0.05$ relative to $\mathrm{E}_{2}+$ vehicle), indicating that activation of ERK or mTOR in the $\mathrm{DH}$ is necessary for $\mathrm{DH}$-infused $\mathrm{E}_{2}$ to increase $\mathrm{MPFC}$ spine density. 
A

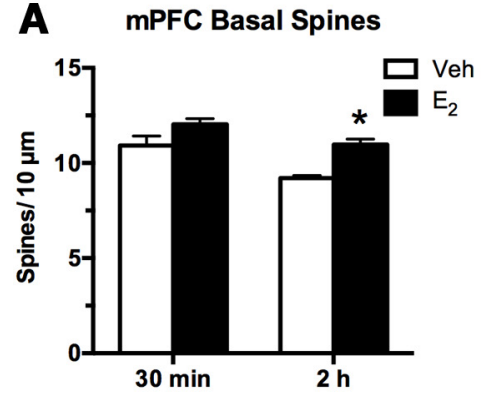

B

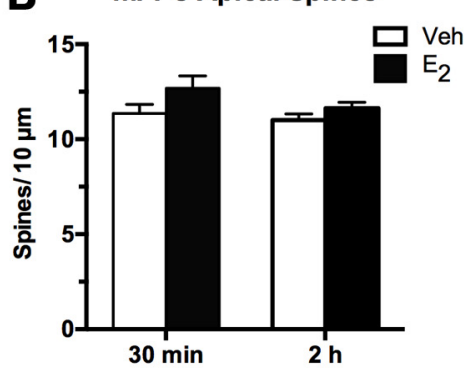

C

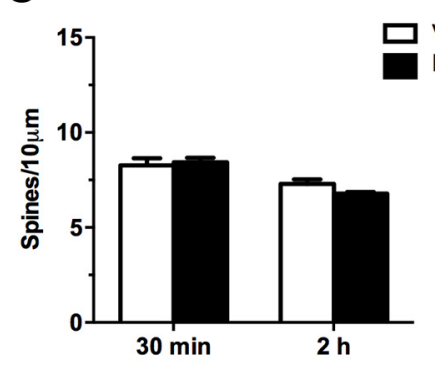

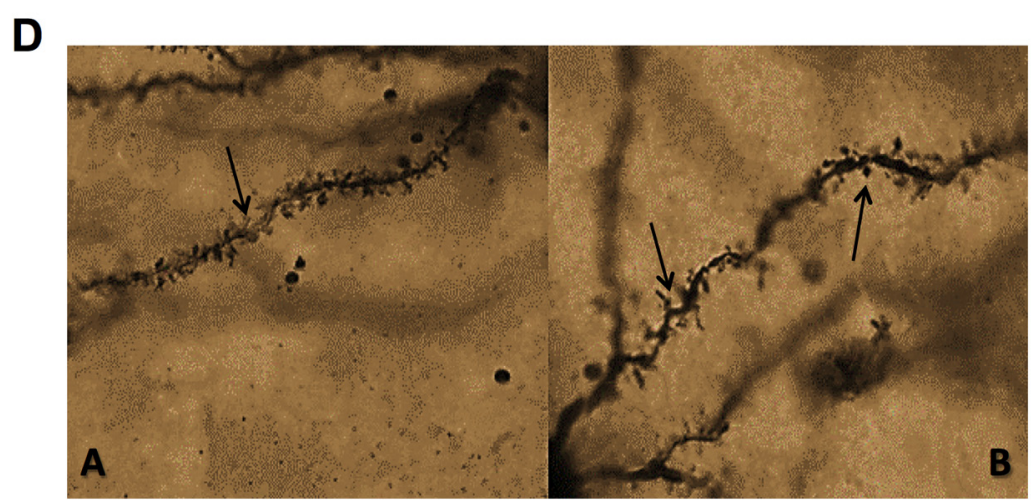

Figure 2. $D H E_{2}$ infusion increased $m P F C$ basal spine density $2 \mathrm{~h}$ later. $\mathrm{mPFC}$ basal spine density was significantly increased relative to vehicle $2 \mathrm{~h}$ after $D H E_{2}$ infusion $(\boldsymbol{A})$. $\mathrm{E}_{2}$ did not significantly alter spine density on $\mathrm{mPFC}$ apical dendrites $(\boldsymbol{B})$ or in the VMN $(\boldsymbol{C})$ at either time point. Bars represent the mean \pm SEM. ${ }^{*} p<0.05$. D, Photomicrograph of Golgi-impregnated secondary basal dendrites of pyramidal cells in the $\mathrm{mPFC}$ (layer II/III; $A, E_{2} ; B$, vehicle). Arrows denote spines. Under oil $100 \times$.

\section{Discussion}

Our findings provide several novel insights into the mechanisms through which $\mathrm{E}_{2}$ induces dendritic spine density in CA1 and mPFC. DH infusion of $E_{2}$ significantly increased basal and apical spine density on CA1 pyramidal dendrites within $30 \mathrm{~min}$, an effect that persisted for $2 \mathrm{~h}$. DH or ICV infusion of $\mathrm{E}_{2}$ also significantly increased basal spine density on $\mathrm{mPFC}$ pyramidal neurons within $2 \mathrm{~h}$. Although systemic $\mathrm{E}_{2}$ injection increases spinogenesis in these brain regions (Inagaki et al., 2012; Luine and Frankfurt, 2012), this is the first demonstration that $\mathrm{DH}$ or ICV $\mathrm{E}_{2}$ infusion increases $\mathrm{CA} 1$ and $\mathrm{mPFC}$ spine density, and that $\mathrm{DH} \mathrm{E}_{2}$ infusion drives mPFC spine changes. Importantly, $\mathrm{DH} \mathrm{E}_{2}$ infusion did not alter spines in the dentate or VMN, suggesting an effect specific to CA1 and mPFC. DH infusion of U0126 or rapamycin blocked the spine increase observed in CA1 and mPFC $2 \mathrm{~h}$ after ICV $\mathrm{E}_{2}$ infusion, indicating that $\mathrm{E}_{2}$-mediated spinogenesis requires ERK and $\mathrm{mTOR}$ activation. Together, these data suggest the involvement of local protein translation in $\mathrm{E}_{2}$-mediated spine alterations, and indicate that $\mathrm{E}_{2}$-induced $\mathrm{DH}$ cell signaling regulates mPFC spine density.

These data provide novel evidence that $\mathrm{E}_{2}$-induced hippocampal alterations impact spine density in the $\mathrm{mPFC}$. The CA1 findings were consistent with classic studies demonstrating that naturally elevated or systemically injected $\mathrm{E}_{2}$ increases CA1 dendritic spine density (Gould et al., 1990; Woolley et al., 1990). The $\mathrm{mPFC}$ findings were more surprising. Although a dose of systemic $\mathrm{E}_{2}$ that enhances hippocampal memory increases CA1 and $\mathrm{mPFC}$ spine density in ovariectomized rats (Inagaki et al., 2012) and mice (Phan et al., 2012), the dependence of spine changes in one region on $\mathrm{E}_{2}$-induced alterations in the other has never been investigated. The present results highlight a previously unexplored interaction between the $\mathrm{DH}$ and $\mathrm{MPFC}$ that may have important implications for understanding how $\mathrm{E}_{2}$ regulates memory. Presently, the mechanisms through which $\mathrm{DH} \mathrm{E}_{2}$ infusion affects $\mathrm{mPFC}$ spine density are unclear. Sparse projections from dorsal CA1 and subiculum to the mPFC exist, as do indirect projections through the nucleus reuniens of the thalamus and ventral hippocampus (Jay et al., 1992; Hoover and Vertes, 2007). The functional relevance of these projections is supported by evidence that collaboration between these brain regions is important for episodic-like memory tasks (Warburton and Brown, 2015) and delayed spatial working memory (Churchwell and Kesner, 2011). Notably, DH $\mathrm{E}_{2}$ infusion affected basal, but not apical, spines in $\mathrm{MPFC}$, which may reflect differences between presynaptic excitatory input to apical and basal domains. For example, input to basal spines in mPFC layer II/III reportedly originates from local circuitry (Spruston, 2008). Therefore, our data suggest that $\mathrm{DH} \mathrm{E}_{2}$ infusion may influence local prefrontal synaptic activity, but additional experiments are necessary to substantiate this interaction. Interestingly, ICV $\mathrm{E}_{2}$ infusion increased both basal and apical spines, which could suggest that the more anterior ICV infusion affects a subpopulation of DH pyramidal neurons that project to both apical and basal dendrites. Nevertheless, blocking ERK and mTOR signaling in the DH prevented ICV-infused $\mathrm{E}_{2}$ from increasing spines in the $\mathrm{MPFC}$, pinpointing the $\mathrm{DH}$ as a key regulator of $\mathrm{ICV} \mathrm{E}_{2}$-mediated spinogenesis.

Our data suggest that ERK and mTOR activation is necessary for $\mathrm{E}_{2}$ to increase CA1 and $\mathrm{MPFC}$ spine density. ERK activation is essential for synaptic plasticity and hippocampal-dependent memory (English and Sweatt, 1997; Atkins et al., 1998; Selcher et al., 1999). Moreover, $\mathrm{E}_{2}$ rapidly increases DH ERK phosphorylation in vitro (Boulware et al., 2005; Zhao and Brinton, 2007) and in vivo (Fernandez et al., 2008), and ERK activation is necessary for $\mathrm{E}_{2}$ to enhance hippocampal-dependent object recognition and spatial memory in female mice (Fernandez et al., 2008; Boul- 
A

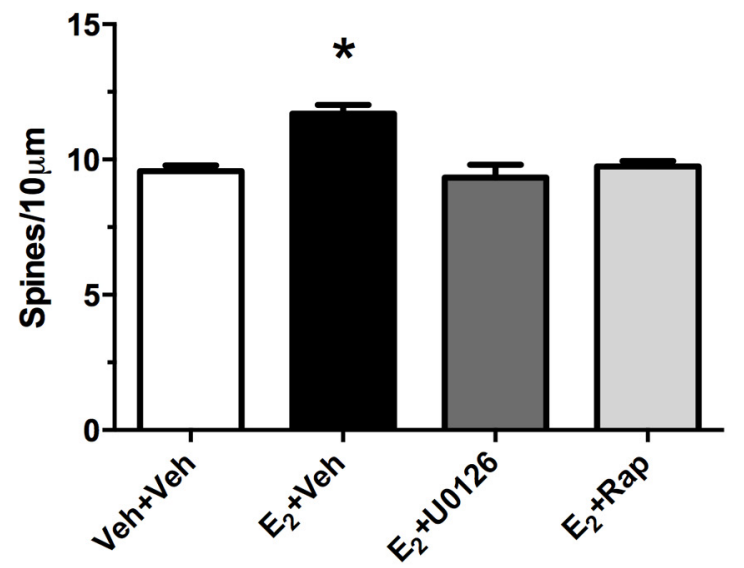

C

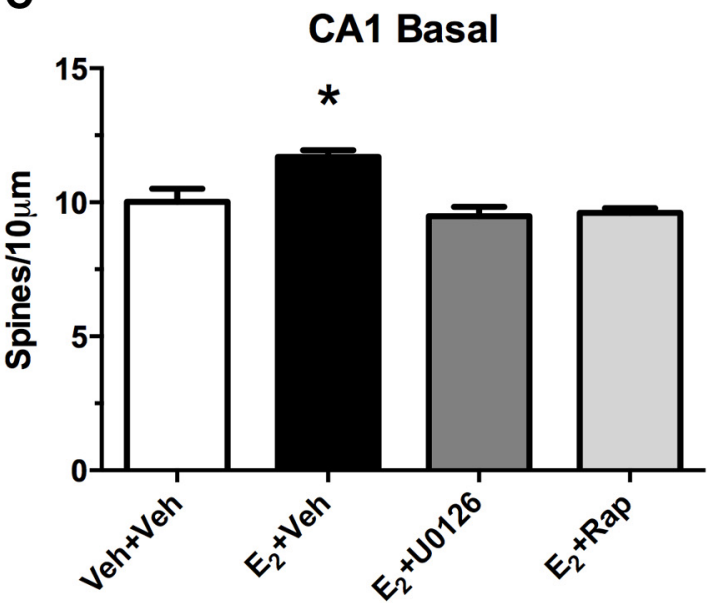

B

mPFC Apical

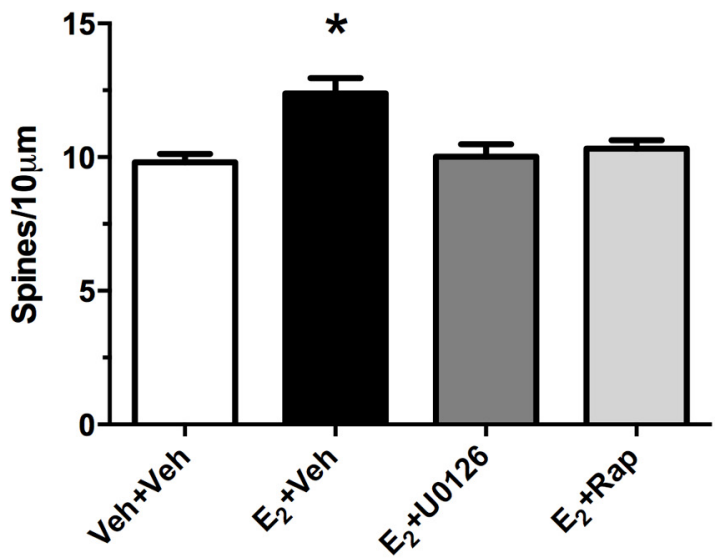

D

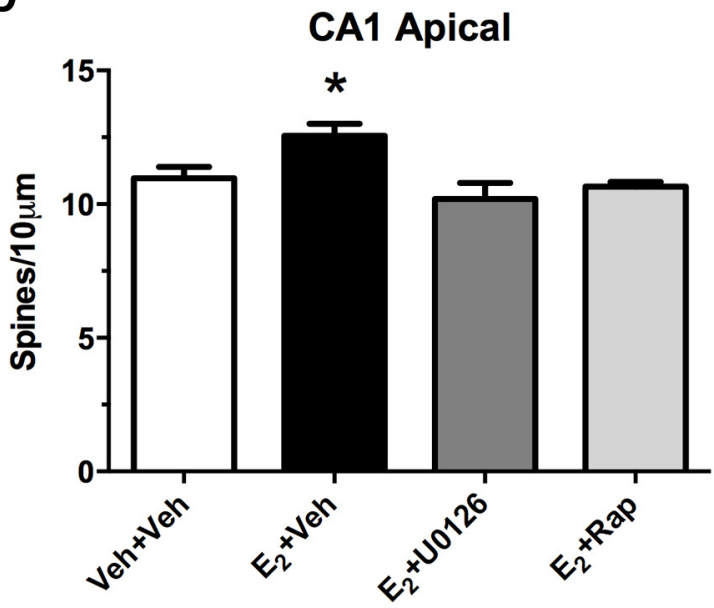

$\mathbf{E}$
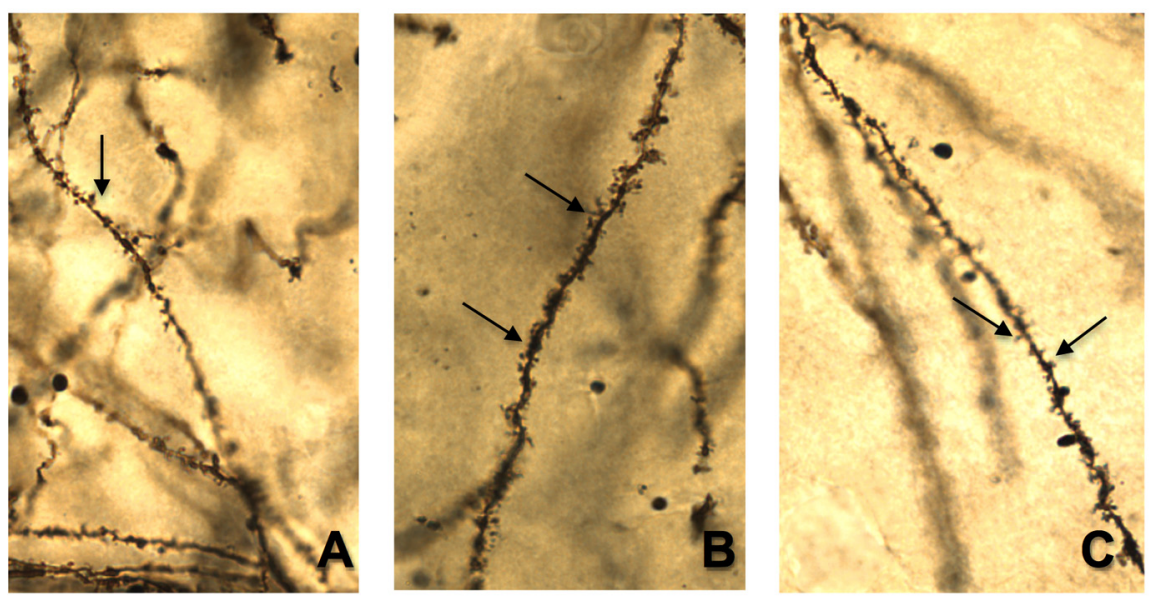

Figure 3. The increased $C A 1$ and $m P F C$ apical and basal spine density induced by ICV $E_{2}$ was blocked by ERK or mTOR inhibition. Two hours after ICV $E_{2}$ infusion, basal and apical spine density was significantly increased in the $\operatorname{mPFC}(\boldsymbol{A}, \boldsymbol{B})$ and $C A 1(\boldsymbol{C}, \boldsymbol{D})$ relative to vehicle. These effects were blocked by DH infusion of U0126 or rapamycin. Bars represent the mean $\pm S E M$. ${ }^{*} p<0.05$ relative to all other groups. $E$, Photomicrograph of Golgi-impregnated secondary basal dendrites of $C A 1$ pyramidal cells ( $A$, vehicle; $B, E_{2}+$ vehicle; $C$, $\left.E_{2}+U 0126\right)$. Arrows denote spines. Under oil $63 \times$.

ware et al., 2013; Fortress et al., 2013). The current work extends these findings by demonstrating that $\mathrm{E}_{2}$-induced ERK activation is also necessary for CA1 and $\mathrm{MPFC}$ spinogenesis in vivo. These results are consistent with in vitro data showing that ERK inhibition blocks $\mathrm{E}_{2}$-induced spinogenesis in the CA1 of male hippocampal slices (Mukai et al., 2007; Hasegawa et al., 2015) and in cortical neuron cultures (Srivastava et al., 2008).
ERK phosphorylation triggers downstream mTOR-mediated protein synthesis (Hoeffer and Klann, 2010), which is also essential for hippocampal synaptic plasticity (Tang et al., 2002) and hippocampal-dependent memory (Bekinschtein et al., 2007; Gafford et al., 2011). Furthermore, ERK-induced activation of mTOR signaling is required for $\mathrm{E}_{2}$ to enhance object recognition memory in female mice (Fortress et al., 2013). Here, rapamycin blocked the 
increased CAl and mPFC spine density $2 \mathrm{~h}$ after $\mathrm{E}_{2}$ infusion, suggesting that $\mathrm{E}_{2}$-mediated spinogenesis depended on $\mathrm{DH}$ mTOR activation. Although $\mathrm{E}_{2}$ increases mTOR phosphorylation in hippocampal slices (Briz and Baudry, 2014), these findings provide the first in vivo demonstration that $\mathrm{mTOR}$ activation is necessary for $\mathrm{E}_{2}$ to increase spine density in either brain region. Interestingly, $\mathrm{E}_{2}-$ induced spinogenesis in the $\mathrm{MPFC}$ required $\mathrm{mTOR}$ activation in the $\mathrm{DH}$, further supporting that $\mathrm{DH}$ cell signaling regulates $\mathrm{mPFC}$ spine density. Together with the aforementioned behavioral and in vitro data, these results suggest that estrogenic activation of mTORmediated protein synthesis may be essential for the local translation of transcripts that support the formation or maintenance of new spines. Because other signaling mechanisms regulate $\mathrm{E}_{2}$-mediated spinogenesis in cultured hippocampal or cortical neurons, including PI3K, PKA, PKC, CaMKII, and the RhoA > ROCK > LIMK > cofilin $>$ actin pathway (Srivastava et al., 2008; Hasegawa et al., 2015), the role of these mechanisms in mediating $E_{2}$-induced spinogenesis in vivo should be tested in future studies.

In conclusion, the present findings demonstrate that $\mathrm{DH} \mathrm{E}_{2}$ infusion rapidly increases $\mathrm{CA} 1$ and $\mathrm{mPFC}$ dendritic spine density in an ERK- and mTOR-dependent fashion. These data shed new light on the molecular mechanisms underlying $\mathrm{E}_{2}$-induced spinogenesis in vivo, and suggest that the $\mathrm{DH}$ and $\mathrm{mPFC}$ may interact to mediate the memory-enhancing effects of $E_{2}$. Because systemic $\mathrm{E}_{2}$ treatments that enhance memory also increase spine density in CA1 and mPFC (Velázquez-Zamora et al., 2012; Luine and Frankfurt, 2013), the current findings have important implications for understanding how estrogenic regulation of neural circuitry influences memory formation.

\section{References}

Atkins CM, Selcher JC, Petraitis JJ, Trzaskos JM, Sweatt JD (1998) The MAPK cascade is required for mammalian associative learning. Nat Neurosci 1:602-609. CrossRef Medline

Barha CK, Lieblich SE, Galea LA (2009) Different forms of oestrogen rapidly upregulate cell proliferation in the dentate gyrus of adult female rats. J Neuroendocrinol 21:155-166. CrossRef Medline

Bekinschtein P, Katche C, Slipczuk LN, Igaz LM, Cammarota M, Izquierdo I, Medina JH (2007) mTOR signaling in the hippocampus is necessary for memory formation. Neurobiol Learn Mem 87:303-307. CrossRef Medline

Boulware MI, Weick JP, Becklund BR, Kuo SP, Groth RD, Mermelstein PG (2005) Estradiol activates group I and II metabotropic glutamate receptor signaling, leading to opposing influences on cAMP response elementbinding protein. J Neurosci 25:5066-5078. CrossRef Medline

Boulware MI, Heisler JD, Frick KM (2013) The memory-enhancing effects of hippocampal estrogen receptor activation involve metabotropic glutamate receptor signaling. J Neurosci 33:15184-15194. CrossRef Medline

Briz V, Baudry M (2014) Estrogen regulates protein synthesis and actin polymerization in hippocampal neurons through different molecular mechanisms. Front Endocrinol (Lausanne) 5:22. CrossRef Medline

Churchwell JC, Kesner RP (2011) Hippocampal-prefrontal dynamics in spatial working memory: interactions and independent parallel processing. Behav Brain Res 225:389-395. CrossRef Medline

English JD, Sweatt JD (1997) A requirement for the mitogen-activated protein kinase cascade in hippocampal long term potentiation. J Biol Chem 272:19103-19106. CrossRef Medline

Fernandez SM, Lewis MC, Pechenino AS, Harburger LL, Orr PT, Gresack JE, Schafe GE, Frick KM (2008) Estradiol-induced enhancement of object memory consolidation involves hippocampal ERK activation and membrane-bound estrogen receptors. J Neurosci 28:8660-8667. CrossRef Medline

Fortress AM, Fan L, Orr PT, Zhao Z, Frick KM (2013) Estradiol-induced object recognition memory consolidation is dependent on activation of mTOR signaling in dorsal hippocampus. Learn Mem 20:147-155. CrossRef Medline

Foy MR, Xu J, Xie X, Brinton RD, Thompson RF, Berger TW (1999) $17 \beta$ estradiol enhances NMDA receptor-mediated EPSPs and long-term potentiation. J Neurophysiol 81:925-929. Medline

Frankfurt M, Gould E, Woolley CS, McEwen BS (1990) Gonadal steroids mod- ify dendritic spine density in ventromedial hypothalamic neurons: a Golgi study in the adult rat. Neuroendocrinology 51:530-535. CrossRef Medline

Frankfurt M, Salas-Ramirez K, Friedman E, Luine V (2011) Cocaine alters dendritic spine density in cortical and subcortical brain regions of the postpartum and virgin female rat. Synapse 65:955-961. CrossRef Medline

Gafford GM, Parsons RG, Helmstetter FJ (2011) Consolidation and reconsolidation of contextual fear memory requires mammalian target of rapamycin-dependent translation in the dorsal hippocampus. Neuroscience 182:98-104. CrossRef Medline

Galea LA, Spritzer MD, Barker JM, Pawluski JL (2006) Gonadal hormone modulation of hippocampal neurogenesis in the adult. Hippocampus 16:225-232. CrossRef Medline

Gould E, Woolley CS, Frankfurt M, McEwen BS (1990) Gonadal steroids regulate dendritic spine density in hippocampal pyramidal cells in adulthood. J Neurosci 10:1286-1291. Medline

Hasegawa Y, Hojo Y, Kojima H, Ikeda M, Hotta K, Sato R, Ooishi Y, Yoshiya M, Chung BC, Yamazaki T, Kawato S (2015) Estradiol rapidly modulates synaptic plasticity of hippocampal neurons: involvement of kinase networks. Brain Res 1621:147-161. CrossRef Medline

Hoeffer CA, Klann E (2010) mTOR signaling: at the crossroads of plasticity, memory and disease. Trends Neurosci 33:67-75. CrossRef Medline

Hoover WB, Vertes RP (2007) Anatomical analysis of afferent projections to the medial prefrontal cortex in the rat. Brain Struct Funct 212:149-179. CrossRef Medline

Inagaki T, Frankfurt M, Luine V (2012) Estrogen-induced memory enhancements are blocked by acute bisphenol $\mathrm{A}$ in adult female rats: role of dendritic spines. Endocrinology 153:3357-3367. CrossRef Medline

Jay TM, Thierry AM, Wiklund L, Glowinski J (1992) Excitatory amino acid pathway from the hippocampus to the prefrontal cortex: contribution of AMPA receptors in hippocampo-prefrontal cortex transmission. Eur J Neurosci 4:1285-1295. CrossRef Medline

Kesner RP, Hunt ME, Williams JM, Long JM (1996) Prefrontal cortex and working memory for spatial response, spatial location, and visual object information in the rat. Cereb Cortex 6:311-318. CrossRef Medline

Luine V, Frankfurt M (2013) Interactions between estradiol, BDNF and dendritic spines in promoting memory. Neuroscience 239:34-45. CrossRef Medline

Luine VN, Frankfurt M (2012) Estrogens facilitate memory processing through membrane mediated mechanisms and alterations in spine density. Front Neuroendocrinol 33:388-402. CrossRef Medline

Luine V, Attalla S, Mohan G, Costa A, Frankfurt M (2006) Dietary phytoestrogens enhance spatial memory and spine density in the hippocampus and prefrontal cortex of ovariectomized rats. Brain Res 1126:183-187. CrossRef Medline

Ma L, Teruya-Feldstein J, Bonner P, Bernardi R, Franz DN, Witte D, CordonCardo C, Pandolfi PP (2007) Identification of S664 TSC2 phosphorylation as a marker for extracellular signal-regulated kinase mediated mTOR activation in tuberous sclerosis and human cancer. Cancer Res 67: 7106-7112. CrossRef Medline

MacLusky NJ, Luine VN, Hajszan T, Leranth C (2005) The 17alpha and 17beta isomers of estradiol both induce rapid spine synapse formation in the CA1 hippocampal subfield of ovariectomized female rats. Endocrinology 146:287-293. CrossRef Medline

Mukai H, Tsurugizawa T, Murakami G, Kominami S, Ishii H, Ogiue-Ikeda M, Takata N, Tanabe N, Furukawa A, Hojo Y, Ooishi Y, Morrison JH, Janssen WG, Rose JA, Chambon P, Kato S, Izumi S, Yamazaki T, Kimoto T, Kawato S (2007) Rapid modulation of long-term depression and spinogenesis via synaptic estrogen receptors in hippocampal principal neurons. J Neurochem 100:950-967. CrossRef Medline

Murakami G, Hojo Y, Ogiue-Ikeda M, Mukai H, Chambon P, Nakajima K, Ooishi Y, Kimoto T, Kawato S (2015) Estrogen receptor KO mice study on rapid modulation of spines and long-term depression in the hippocampus. Brain Res 1621:133-146. CrossRef Medline

Phan A, Gabor CS, Favaro KJ, Kaschack S, Armstrong JN, MacLusky NJ, Choleris E (2012) Low doses of $17 \beta$-estradiol rapidly improve learning and increase hippocampal dendritic spines. Neuropsychopharmacology 37:2299-2309. CrossRef Medline

Selcher JC, Atkins CM, Trzaskos JM, Paylor R, Sweatt JD (1999) A necessity for MAP kinase activation in mammalian spatial learning. Learn Mem 6:478-490. CrossRef Medline

Spruston N (2008) Pyramidal neurons: dendritic structure and synaptic integration. Nat Rev Neurosci 9:206-221. CrossRef Medline 
Srivastava DP, Woolfrey K, Jones KA, Shum CY, Lash LL, Swanson GT, Penzes P (2008) Rapid enhancement of two-step wiring plasticity by estrogen and NMDA receptor activity. Proc Natl Acad Sci U S A 105: 14650-14655. CrossRef Medline

Tanapat P, Hastings NB, Gould E (2005) Ovarian steroids influence cell proliferation in the dentate gyrus of the adult female rat in a dose- and time-dependent manner. J Comp Neurol 481:252-265. CrossRef Medline

Tang SJ, Reis G, Kang H, Gingras AC, Sonenberg N, Schuman EM (2002) A rapamycin-sensitive signaling pathway contributes to long-term synaptic plasticity in the hippocampus. Proc Natl Acad Sci U S A 99: 467-472. CrossRef Medline

Velázquez-Zamora DA, Garcia-Segura LM, González-Burgos I (2012) Effects of selective estrogen receptor modulators on allocentric working memory performance and on dendritic spines in medial prefrontal cortex pyramidal neurons of ovariectomized rats. Horm Behav 61: 512-517. CrossRef Medline

Warburton EC, Brown MW (2015) Neural circuitry for rat recognition memory. Behav Brain Res 285:131-139. CrossRef Medline

Winter JN, Jefferson LS, Kimball SR (2011) ERK and Akt signaling pathways function through parallel mechanisms to promote mTORC1 signaling. Am J Physiol Cell Physiol 300:C1172-C1180. CrossRef Medline

Woolley CS, McEwen BS (1993) Roles of estradiol and progesterone in regulation of hippocampal dendritic spine density during the estrous cycle in the rat. J Comp Neurol 336:293-306. CrossRef Medline

Woolley CS, Gould E, Frankfurt M, McEwen BS (1990) Naturally occurring fluctuation in dendritic spine density on adult hippocampal pyramidal neurons. J Neurosci 10:4035-4039. Medline

Woolley CS, Weiland NG, McEwen BS, Schwartzkroin PA (1997) Estradiol increases the sensitivity of hippocampal CA1 pyramidal cells to NMDA receptor-mediated synaptic input: correlation with dendritic spine density. J Neurosci 17:1848-1859. Medline

Yang ST, Shi Y, Wang Q, Peng JY, Li BM (2014) Neuronal representation of working memory in the medial prefrontal cortex of rats. Mol Brain 7:61. CrossRef Medline

Zhao L, Brinton RD (2007) Estrogen receptor $\alpha$ and $\beta$ differentially regulate intracellular $\mathrm{Ca}^{2+}$ dynamics leading to ERK phosphorylation and estrogen neuroprotection in hippocampal neurons. Brain Res 1172:48-59. CrossRef Medline 